\title{
Biochemical studies in marine species - II. NADP+-dependent isocitrate dehydrogenase from turbot (Scophthalmus maximus L.) larvae
}

R. Munilla-Morán

Instituto de Investigaciones Marinas, C.S.I.C., Eduardo Cabello, 6. E-36208 Vigo

(Pontevedra), Spain

Correspondence to: R. Munilla-Morán, Instituto de Investigaciones Marinas, C.S.I.C., Eduardo Cabello, 6. E-36208, Vigo (Pontevedra), Spain

The isocitrate dehydrogenase activity specific for $\mathrm{NADP}^{+}$has been studied in early turbot larvae and compared with that of their adult counterparts. The activity showed a broad optimum $\mathrm{pH}$ between 7.9 and 9.0, and an optimum temperature of $40^{\circ} \mathrm{C}$ (with an $\mathrm{E}_{\mathrm{a}}$ of $23.3 \mathrm{~kJ} /$ tool) and was inhibited by high ionic strength and heavy metals. The apparent $\mathrm{K}_{\mathrm{m}}$ values for the substrates were $16.7 \mu \mathrm{M}$ for isocitrate, 3.5 for NADP ${ }^{+}, 29.6$ $\mu \mathrm{M}$ for $\mathrm{Mg}^{2+}$ and $3.3 \mu \mathrm{M}$ for the $\mathrm{Mg}$-isocitrate complex. The effect of the absence of $\mathrm{Mg}^{2+}$ on the enzyme affinity for its substrates is also reported. The enzyme stability was decreased by iodoacetic acid and this effect reverted by isocitrate. The enzyme activity was inhibited by metabolites such as citrate, oxoglutarate and adenine dinucleotides. It was also fully inhibited by the concerted action of glyoxylate and oxaloacetate.

Key words: Isocitrate dehydrogenase; Scophthalmus maximus.

Introduction

Most of the research work carried out with fish larvae has been focused on (a) the biochemical composition of the larvae (protein, carbohydrate and lipid content) and (b) their responses to rearing techniques (food composition and prey density) and abiotic factors (temperature, salinity, dissolved oxygen and light). However little attention has been paid to intermediary metabolism (Laurence, 1975; Cetta and Capuzzo, 1982; Hinterleitner et al., 1987; Santos and Vinagre, 1991).

NADPH is the coenzyme used in fatty acid and sterol synthesis (Baldwin and Reed, 
1976). This can be generated by four enzymes: glucose 6-phosphate dehydrogenase, 6phosphogluconate dehydrogenase, malic enzyme and $\mathrm{NADP}^{+}$-dependent isocitrate dehydrogenase (ICDH). In a previous study (Munilla-Morán et al., 1989) on very early turbot larvae the importance of the ICDH during these stages was pointed out as it represented $70-80 \%$ of the whole NADPH-producing enzymic activity. This enzyme has been extensively studied in adult turbot liver (Munilla-Morán and Stark, 1989).

The enzyme was characterized for sake of comparison with the same enzymes isolated from other sources and to ascertain if the activity found in larvae is the same as that of adult liver, thereby supporting the fact that, at these early ages, there are functional hepatocytes in turbot (Cousin and Baudin Laurencin, 1985).

Materials and Methods

Samples

Turbot (Scophthalmus maximus L.) larvae were obtained from the hatchery Cultivos de Peces, S.A. (O Grove, Pontevedra, Spain). The larvae were collected 3 days after hatching before any feeding so that bias due to diet could be discarded.

For this study, larvae from 15 different batches (collected between April and June of 1992) were pooled (at a density of 100 larvae per $\mathrm{ml}$ ) and the enzymic extracts prepared as for the adult liver enzyme (Munilla-Morán and Stark, 1989). Following dialysis and the second centrifugation, the supernatants were deepfrozen $\left(-18^{\circ} \mathrm{C}\right)$ in small aliquots $(0.2 \mathrm{ml})$ until use. Dilutions were made when necessary. The extraction procedure was carried out in the cold $\left(4^{\circ} \mathrm{C}\right)$.

Isocitrate dehydrogenase activity

The enzymic activity was measured spectrophotometrically following the increase in absorbance at $340 \mathrm{~nm}$ from the production of NADPH, after a modification of the method of Martin and Denton (1970). In a final volume of $1.0 \mathrm{ml}$ made of Tris-HC1 $0.05 \mathrm{M}, \mathrm{pH} 7.8, \mathrm{MgCl}_{2} 2 \mathrm{mM}$, DL-isocitrate $1 \mathrm{mM}$ and NADP $0.1 \mathrm{mM}, 30$ to $50 \mu 1$ of larval extract were normally used. The reaction was started by the addition of NADP 
and the increase in absorbance recorded after 2 min of lag time (Goldberg and Ellis, 1983). Only the linear part of the record graph was considered. One unit (U) was defined as the amount of enzymic extract able to catalyze the production of $1 \mu \mathrm{mol}$ NADPH in $1 \mathrm{~min}$, under the above-described conditions. A molar coefficient of 6.3 for NADPH was used in all calculations (Biochemica Information, 1987).

Soluble protein

Soluble protein was measured following Lowry's method (Lowry et al., 1951) as modified by Miller (1959), using bovine serum albumin (BSA) as standard.

Chemicals

All the chemicals and reagents used in this work were of analytical grade (Sigma, St Louis, MO), unless otherwise stated.

Results

To study the ability of the enzyme to use NAD and/or NADP as coenzyme, the activity was measured in the presence of these compounds. The results obtained are shown in Table 1 . No activity could be detected unless NADP was included in the reaction mixture. An inhibitory effect of NAD was not seen even using NAD/NADP ratios of 10 in the assay. ADP did not stimulate the activity with any of the coenzymes.

The effect of $\mathrm{pH}$ on the activity was measured as stated in Materials and Methods but using the following buffers: imidazole- $\mathrm{HCl}$, Tris- $\mathrm{HCl}$ and glycine- $\mathrm{NaOH}$, all at $0.1 \mathrm{M}$ concentration. The enzyme showed an optimum $\mathrm{pH}$ range between 7.8 and 9.0 (Fig. 1A), sharply decreasing at more alkaline $\mathrm{pH}$ values. The effect of $\mathrm{pH}$ on the stability of the enzymic activity was tested by diluting the extracts in buffers $(0.1 \mathrm{M})$, of different $\mathrm{pH}$ values, and incubating for $2 \mathrm{hr}$, at $30^{\circ} \mathrm{C}$. The remaining activity was measured as in Materials and Methods. The results are presented in Fig. 1B. The activity was shown to be stable within a broad range of $\mathrm{pH}(5.5-7.5)$.

The maximum activity was found at $40^{\circ} \mathrm{C}$, decreasing for higher temperatures (Fig. 2A). 
The $\mathrm{Q}_{10}$ coefficient averaged 1.72 in the range of $20-35^{\circ} \mathrm{C}$, and 3.10 for lower temperatures. The activation energy $\left(\mathrm{E}_{\mathrm{a}}\right)$ calculated from the slope of the Arrhenius plot had a value of $23.3 \mathrm{~kJ} / \mathrm{mol}$ (Fig. 2B).

ICDH activity was inhibited by high salt concentrations (Fig. 3). The strongest inhibition was found with salts of divalent cations. Also studied was the affinity of the ICDH by isocitrate, NADP and magnesium ions by measuring the enzymic activity at several concentrations of these compounds. The affinity for isocitrate and NADP was determined in presence and absence of $\mathrm{MgCl}_{2}(2 \mathrm{mM})$. The results obtained are shown in Figs 4-6. In all cases hyperbolic curves were obtained. The $\mathrm{K}_{\mathrm{m}}$ values (calculated from Lineweaver-Burk plots) were: 16.7 and $623.9 \mu \mathrm{M}$ for isocitrate (in the presence and the absence of $\mathrm{Mg}^{2+}$, respectively); 3.5 and 36.5 for NADP and $29.6 \mu \mathrm{M}$ for magnesium.

Farrell (1980) working with ICDH from bovine mammary gland found a protective effect of dithiothreitol on the stability of the enzyme. The larval enzyme was incubated with dithiothreitol and/or 2-mercaptoethanol for $30 \mathrm{~min}$ at room temperature and the remaining activities measured. The results are presented in Table 2. A noteworthy effect could not be detected.

Inhibition of the enzyme by means of carboxymethylating compounds has also been reported (Colman, 1968). The larval ICDH was incubated for $2 \mathrm{hr}$ at $30^{\circ} \mathrm{C}$ with iodoacetic acid $(30 \mathrm{mM})$, at several $\mathrm{pH}$ values, in the presence and the absence of substrate (isocitrate $30 \mathrm{mM}$ ). The remaining activity was determined and plotted $\mathrm{vs} \mathrm{pH}$ (Fig. 7). Iodoacetate also showed an inhibitory effect on turbot larval ICDH being, at neutral $\mathrm{pH}$, the strongest inhibitor. Isocitrate prevented any deleterious effect in all the $\mathrm{pH}$ ranges tested.

Larval ICDH activity was measured in the presence of several metabolites (all but one of them belonging to the Krebs cycle) at two substrate concentrations (0.1 and $1.0 \mathrm{mM})$. The results obtained (expressed as a percentage of the control) are shown in Table 3. Paramount inhibitory effects were detected with the concerted action of glyoxylate and oxaloacetate despite the fact that these two compounds had a negligible effect when 
assayed separately, even at higher concentrations. Citrate and oxoglutarate also inhibited the activity; the stronger the effect, the lower the isocitrate concentration. The effect of adenine nucleotides on ICDH activity was measured in the presence of different concentrations of AMP, ADP and ATP, using a final $\mathrm{Mg}^{2+}$ concentration of 1 $\mathrm{mM}$. The resulting activities are shown in Table 4 . In all cases, the activity measured was lower than that of the control. The strongest inhibition was found for ATP.

\section{Discussion}

One of the aims of this work was to test the similarity between the ICDH activity found in turbot larvae and that of adult liver. In adult turbot liver there seems to be only one enzyme specific for NADP as coenzyme (Munilla-Moran and Stark, 1989), and identical findings have been reported for other marine species (Moon and Hochachka, 1971; Head and Gabbott, 1980; Ruiz-Ruano et al., 1985). In mammals, although NADP-dependent ICDH has been extensively purified and characterized (Colman, 1969; Illinworth and Tipton, 1970; Farrell, 1980), the presence of NAD-dependent ICDH is well established (McGilvery and Goldstein, 1983; Martin, 1987; Saier, 1987). The latter is activated by ADP and AMP (Saier, 1987; Rasschart and Malaisse, 1992). The larval ICDH enzyme was active only with NADP as coenzyme but I failed to find measurable activity with $10 \mathrm{mM}$ of ADP in the assay and NAD as coenzyme (see Table $1)$.

Fish are ectothermic animals that, apart from adapting to availability of food, must also cope with other abiotic factors such as temperature, salinity, oxygen level, etc. (Jürss et al., 1985). This is especially true of the much more fragile larval stages. The optimum $\mathrm{pH}$ found for the enzyme in larvae compares well with that of adult turbot liver (Munilla-Morán and Stark, 1989) and other sources (Farrell, 1980; Head and Gabbott, 1980; Ruiz-Ruano et al., 1985; Williamson et al., 1980). However the optimum pH for stability of this enzyme was almost $2 \mathrm{pH}$ units lower than that found for activity.

There were differences in the response against temperature between the larval and adult enzymes extracted from turbot (Munilla-Morán and Stark, 1989). The larval enzyme showed a lower optimum temperature $\left(40^{\circ} \mathrm{C}\right)$ than that found in adults $\left(50-70^{\circ} \mathrm{C}\right)$, and a higher $\mathrm{Q}_{10}$ for a range of temperatures under which intensive rearing is carried out 
(Jones, 1972; Quantz, 1985). The Ea value obtained in this study $(23.3 \mathrm{~kJ} / \mathrm{mol})$ was close to that reported for adult turbot liver (23.5 kJ/tool) (Munilla-Morán and Stark, 1989 ) but was far from that found in warm-acclimated rainbow trout $(74.1 \mathrm{~kJ} / \mathrm{mol})$ (Moon and Hochachka, 1971). This might imply more drastic effects on turbot larvae intermediary metabolism when small changes in environmental temperatures occurs compared to those expected in adults.

Inhibition of the activity by high salt levels has also been reported in human (Ellis and Goldberg, 1971) and bovine (Farrell, 1980) enzymes. An inhibitory effect of heavy metals on this activity has also been detected (Islam et al., 1972; Yoshino et al., 1992). Both findings have been explained as a substitution of the magnesium ion by these cations. The mechanism of this inhibition seems to be that high ionic strength (or elevated temperatures) increases the equilibrium constant of the reaction towards the production of oxoglutarate and NADPH. Conversely, higher concentrations of magnesium decrease the equilibrium constant (Londesborough and Dalziel, 1968). On the other hand, both products have been demonstrated to be inhibitors of the isocitrate dehydrogenase activity (Illinworth and Tipton, 1970; Munilla-Morán and Stark, 1989; this work).

The small amounts of turbot larvae available made it very difficult to proceed to further purification of the enzyme. However, the $\mathrm{K}_{\mathrm{m}}$ constants found in this study were in the range of those reported for more purified $\mathrm{NADP}^{+}$-dependent ICDHs (Nicholls and Garland, 1969; Farrell, 1980; Head and Gabbott, 1980; Williamson et al., 1980; RuizRuano et al., 1985). These constants also fitted very well with those determined in adults (Munilla-Morán and Stark, 1989). All this suggests that unspecific interactions did not affect the ICDH. It has been reported that the true substrate of the enzyme is the metal-isocitrate complex instead of isocitrate alone (Carlier and Pantaloni, 1973). As the dissociation constant of this complex was $5 \mathrm{mM}$, the apparent affinity constant for $\mathrm{Mg}$ isocitrate was $3.3 \mu \mathrm{M}$. Very different $\mathrm{K}_{\mathrm{m}}$ values for isocitrate and NADP were found when the ICDH activity was measured in the absence of magnesium (see Figs 4 and 5, respectively). The extract retained all ICDH activity after extensive dialysis against buffered chelating agents (EDTA) (data not shown). These findings suggested that this ion was essential for the activity of this enzyme, but not for its stability. 
The fruitless attempt to enhance ICDH stability with SH-group reducing agents might indicate the absence "of sulfhydryl or other oxidizable groups in or near the active site" of the enzyme. This is against that proposed by Farrell (1980). On the other hand, iodoacetate decreased ICDH stability (this effect being avoided by the presence of the substrate), suggesting that the group to be carboxymethylated was close to, or belonged to, the active centre (Colman, 1968).

Isocitrate dehydrogenase plays an important role in the intermediary metabolism of the cell. Key enzymes are usually regulated by a number of metabolites (Saier, 1987; Martin, 1987). NADP ${ }^{+}$-dependent isocitrate dehydrogenase from turbot larvae is inhibited by the concerted action of glyoxylate and oxaloacetate. This effect has been found in all isocitrate dehydrogenases studied so far (Farrell, 1980; Head and Gabbott, 1980; Moon and Hochachka, 1971; Munilla-Morán and Stark, 1989) and appeared to be a feature of this enzyme. Glyoxylate is characteristic of the glyoxylate cycle but this has never been detected in vertebrates (Cioni et al., 1981; Vanni et al., 1990). The physiological meaning of this inhibition is unknown (Illinworth and Tipton, 1970) but seems to be unimportant (Head and Gabbott, 1980).

Inhibition of turbot larval $\mathrm{NADP}^{+}$dependent isocitrate dehydrogenase by oxoglutarate was also found in adult turbot (Munilla-Morán and Stark, 1989) and rainbow trout (Moon and Hochachka, 1971). These authors proposed a competitive inhibitory mechanism for this metabolite. However, it should be borne in mind that oxoglutarate is one of the products of the reaction catalysed by this enzyme and other types of effect on its activity ought to be investigated.

Inhibition of the enzymic activity by citrate and nucleotides (see Tables 3 and 4, respectively) was also found for the enzyme of adults (Munilla-Morán and Stark, 1989) where they acted as competitive inhibitors. This inhibition was thought to occur by sequestration of the magnesium ion from the enzyme (Moon and Hochachka, 1971). The role of adenine nucleotides on ICDH activity modulation has been extensively studied but a general pattern cannot be established. In mammals, ATP acts as a potent inhibitor; meanwhile, ADP (and AMP) activates the enzyme, lowering its $\mathrm{K}_{\mathrm{m}}$ for isocitrate by an order of magnitude (McGilvery and Goldstein, 1983; Saier, 1987). In rainbow trout liver, $40 \%$ inhibition was reported when the enzyme was measured in the 
presence of ATP $(1 \mathrm{mM})$ or ADP $(5 \mathrm{mM})$, with $0.1 \mathrm{mM}$ isocitrate and $1 \mathrm{mM} \mathrm{Mg}^{2+}$ in the assay (Moon and Hochachka, 1971). No inhibition was found with AMP under the same assay conditions. Head and Gabbott (1970) did not find inhibition by ATP and ADP (5 $\mathrm{mM}$ ) on ICDH from the mussel Mytilus edulis.

Conclusion

One of the goals of this study was to determine if the ICDH activity present in early turbot larvae was the same or similar to that found in adult liver.

The results obtained in most of the experiments carried out in this work were very similar for both enzymes except for the effect of the temperature on the ICDH activity (Munilla-Morán and Stark, 1989). Torrissen (1984) showed that small differences in optimum temperatures for trypsin-like activities from Atlantic salmon and rainbow trout were correlated with different zymograms.

Bearing this in mind, it cannot be accurately concluded that the ICDH activities detected in whole larvae and adult liver are due to the same enzyme in turbot, despite their high similarities in most of the characteristics studied in this work.

The use of electrophoretic techniques in early fish larvae may be handicapped by the small amounts of raw material usually available.

Acknowledgements - I thank J. L. Rodriguez and J. J. Otero, biologists of Cultivos de Peces, S. A. (O Grove, Pontevedra, Spain) for larval supplies, and L. Nieto and E. Calvar for technical assistance. This work has been supported by a grant from the Xunta de Galicia No. XUGA40201B90.

\section{References}

Baldwin J. and Reed K. C. (1976) Cytoplasmic sources of NADPH for fat synthesis in rainbow trout liver: effect of thermal acclimation on enzyme activity. Comp. Biochem. Physiol. 54B, 527-529. 
Biochemica Information (1987) (Edited by Keesey J.), 1st edn, 246 pp. Boehringer Mannheim Biochemicals, Indianapolis, IN.

Carlier M. F. and Pantaloni D. (1973) NADP-isocitrate dehydrogenase from beef liver. Purification, quaternary structure and catalytic activity. Eur. J. Biochem. 37, 341354.

Cetta C. M. and Capuzzo J. M. (1982) Physiological and biochemical aspects of embryonic and larval development of the winter flounder Pseudopleuronectes americanus. Mar. Biol. 71, 327-337.

Cioni M., Pinzauti G. and Vanni P. (1981) Comparative biochemistry of the giyoxylate cycle. Comp. Biochem. Physiol. 70B, 1-26.

Colman R. F. (1969) Effect of modification of a methionyl residue on the kinetic and molecular properties of isocitrate dehydrogenase. J. biol. Chem. 243, 2454-2464.

Cousin J. C. B. and Baudin Laurencin F. (1985) Morphogenèse de l'appareil digestif et de la vessie gazeuse du turbot, Scophthalmus maximus L. Aquaculture 47, 305-319. Ellis G. and Goldberg D. M. (1971) An improved manual and semi-automatic assay for NADP-dependent isocitrate dehydrogenase activity, with description of some kinetic properties of human liver and serum enzyme. Clin. Biochem. 2, 175-185.

Farrell H. M. Jr (1980) Purification and properties of NADP ${ }^{+}$: isocitrate dehydrogenase from lactating bovine mammary gland. Archs Biochem. Biophys. 204, 551-559.

Goldberg D. M. and Ellis G. (1983) Isocitrate dehydrogenase. In Methods of Enzymatic Analysis (Edited by Bergmeyer H. U.), 3rd edn, Vol. 3, pp. 183-190.

Head E. J, H. and Gabbott P. A. (1980) Properties of NADP-dependent isocitrate dehydrogenase from the mussel Mytilus edulis L. Comp. Biochem. Physiol. 66B, 285-289.

Hinterleitner S., Platzer U. and Wieser W. (1987) Development of the oxidative, giycolytic and muscle enzymes during early larval life in three families of freshwater fish. J. Fish Biol. 30, 315-326.

Illinworth J. A. and Tipton K. F. (1970) Purification and properties of the nicotinamideadenine dinueleotide phosphate-dependent isocitrate dehydrogenase from pig liver cytoplasm. Biochem. J. 118, 253-258.

Islam M., Bell J. L. and Baron D. N. (1971) Purification and comparative properties of isoenzymes of nicotinamide-adenine dinucleotide phosphate-isocitrate dehydrogenase from rat heart and liver. Biochem. J. 129, 1003-1011. 
Jones A. (1972) Studies on egg development and larval rearing of turbot, Scophthalmus maximus L., and brill, Scophthalmus rhombus L., in the laboratory. J. mar. biol. Ass. U.K. 52, 965-986.

Jürss K., Bittorf Th. and Völker Th. (1985) Influence of salinity and ratio of lipid to protein in diets of certain enzyme activities in rainbow trout (Salmo gairdneri Richardson). Comp. Biochem. Physiol. 81B, 73-79.

Laurence G. C. (1975) Laboratory growth and metabolism of the winter flounder Pseudopleuronectes americanus from hatching through metamorphosis at three temperatures. Mar. Biol. 32, 223-229.

Londesborough J. C. and Dalziel K. (1968) The equilibrium constant of the isocitrate dehydrogenase reaction. Biochem. J. 110, 217-222.

Lowry O. H., Rosebrough N. J., Farr A. L. and Randall R. J. (1951). Protein measurement with the Folin phenol reagent. J. biol. Chem. 193, 265-275.

Martin B, R. (1987) Metabolic Regulation. A Molecular Approach, 299 pp. Blackwell Scientific, Oxford.

Martin B. R. and Denton R. M. (1970) The intracellular localizations of enzymes in the white-adipose-tissue fat-cells and permeability properties of fat-cell mitochondria: transfer of acetyl units and reducing power between mitochondria and cytoplasm. Biochem. J. 117, 861-877.

McGilvery R. W. and Goldstein G. W. (1983) Biochemistry. A Functional Approach. 3rd edn, 909 pp. W. B. Saunders, Tokyo, Japan.

Miller G. L. (1959) Protein determination for large number of samples. Analyt. Chem. $31,964$.

Moon T. W. and Hochachka P. W. (1971) Temperature and enzyme activity in poikilotherms. Isocitrate dehydrogenase in rainbow trout. Biochem. J. 123, 695-705. Munilla-Morán R. and Stark J. R. (1989) Biochemical studies in marine species-I. $\mathrm{NADP}^{+}$-dependent isocitrate dehydrogenase from turbot liver (Scophthalmus maximus L.). Comp. Biochem. Physiol. 93B, 823-828.

Munilla-Morán R., Barbour A. and Stark J. R. (1989) NADPH generation in turbot larvae: a practical approach. Worm Aquacult. 20, 78-79.

Nicholls D. G. and Garland P. B. (1969) The control of isocitrate dehydrogenase by rat liver mitochondria. Biochem. J. 114, 215-225.

Quantz G. (1985) Use of endogenous energy sources by larval turbot Scophthalmus maximus. Trans. Am. Fish. Soc. 114, 558-563. 
Rasschaert J. and Malaisse W. J. (1992) Hexose metabolism in pancreatic cells.

Regulation of NAD-isocitrate dehydrogenase activity. Biochem. Med. Metab. Biol. $48,32-40$.

Ruiz-Ruano A., Herranz Santos M. J. and Ruiz-Amil M. (1985) NADP ${ }^{+}$-dependent isocitrate dehydrogenase from hepatopancreas of mussel (Mytilus edulis L.). Comp. Biochem. Physiol. 81B, 953-957.

Saier M. H. (1987) Enzymes in Metabolic Pathways: A Comparative Study of Mechanism, Structure, Evolution, and Control, 246 pp. Harper \& Row, New York.

Santos E. A. and Vinagre A. S. (1991) Carbohydrate metabolism during embryonic and larval development of Odonthetes humensis (De Buen, 1953) (Pisces-Atherinidae). J. Fish Biol. 39, 239-244.

Torrissen K. R. (1984) Characterization of proteases in the digestive tract of Atlantic salmon (Salmo salar) in comparison with rainbow trout (Salmo gairdneri). Comp. Biochem. Physiol. 77B, 669-674.

Vanni P., Giachetti E., Pinzauti G. and McFadden B. A. (1990) Comparative structure, function and regulation of isocitrate lyase, an important assimilatory enzyme. Comp. Biochem. Physiol. 95B, 431-458.

Williamson J. H., Krochko D. and Bentley M. M. (1980) Properties of Drosophila $\mathrm{NADP}^{+}$-isocitrate dehydrogenase purified on Procion Brilliant Blue-Sepharose-4B. Comp. Biochem. Physiol. 65B, 339-343.

Yoshino M., Yamada Y. and Murakami K. (1992) Inhibition by aluminium ion of NAD- and NADP-dependent isocitrate dehydrogenases from yeast. Int. J. Biochem. $24,1615-1618$. 
Table 1. Turbot larvae ICDH coenzyme specificity

\begin{tabular}{|c|c|c|}
\hline Composition (coenzyme) & $\begin{array}{l}\text { mUnits/ mg } \\
\text { protein }\end{array}$ & $\begin{array}{l}\text { Relative } \\
\text { activity }\end{array}$ \\
\hline $\mathrm{NADP}^{+} 0.1 \mathrm{mM}$ (Control) & 27.57 & 100.0 \\
\hline $\mathrm{NAD}^{+} 0.1 \mathrm{mM}$ & 0 & 0 \\
\hline $\mathrm{NAD}^{+} 1.0 \mathrm{mM}$ & 0 & 0 \\
\hline $\mathrm{NADP}^{+} 0.1 \mathrm{mM}+\mathrm{NAD}^{+} 0.1 \mathrm{mM}$ & 27.49 & 99.7 \\
\hline $\mathrm{NADP}^{+} 0.1 \mathrm{mM}+\mathrm{NAD}^{+} 1.0 \mathrm{mM}$ & 27.34 & 99.2 \\
\hline $\mathrm{NAD}^{+} 1.0 \mathrm{mM}+\mathrm{ADP} 5.0 \mathrm{mM}$ & 0 & 0 \\
\hline $\mathrm{NAD}^{+} 1.0 \mathrm{mM}+\mathrm{ADP} 10.0 \mathrm{mM}$ & 0 & 0 \\
\hline $\begin{array}{l}\mathrm{NADP}^{+} 0.1 \mathrm{mM}+\mathrm{NAD}^{+} 1.0 \mathrm{mM}+\mathrm{ADP} 1.0 \\
\mathrm{mM}\end{array}$ & 27.43 & 99.5 \\
\hline $\begin{array}{l}\mathrm{NADP}^{+} 0.1 \mathrm{mM}+\mathrm{NAD}^{+} 1.0 \mathrm{mM}+\mathrm{ADP} 5.0 \\
\mathrm{mM}\end{array}$ & 27.43 & 99.5 \\
\hline
\end{tabular}

Table 2. The effect of sulphydryl group reducing agents on turbot larvae ICDH stability

\begin{tabular}{|l|l|l|}
\hline Compound (concentration) & $\begin{array}{l}\text { Specific activity } \\
\text { (mUnits/mg protein) }\end{array}$ & Remaining activity (\%) \\
\hline None (Control) & 33.16 & 100.0 \\
\hline Dithiothreitol $(5 \mathrm{mM})$ & 34.25 & 103.3 \\
\hline Dithiothreitol $(10 \mathrm{mM})$ & 34.21 & 103.5 \\
\hline $\begin{array}{l}\beta-\text { Mercaptocthanol }(5 \mathrm{mM}) \\
\beta \text {-Mercaptocthanol }(10\end{array}$ & 32.12 & 96.9 \\
\hline $\mathrm{mM})$ & 33.33 & 100.5 \\
\hline $\begin{array}{l}\text { Dithiothreitoi }(5 \mathrm{mM})+\beta- \\
\text { mercaptoethanoi }(5 \mathrm{mM})\end{array}$ & 32.58 & 98.3 \\
\hline
\end{tabular}

Table 3. Effect of various metabolites on the activity of ICDH from turbot larvae

\begin{tabular}{|c|c|c|c|}
\hline \multirow{2}{*}{ Metabolite } & \multirow[b]{2}{*}{ Concentration } & \multicolumn{2}{|c|}{ Relative activity (\%) } \\
\hline & & $1.0 \mathrm{mM}$ & $0.1 \mathrm{mM}$ \\
\hline
\end{tabular}




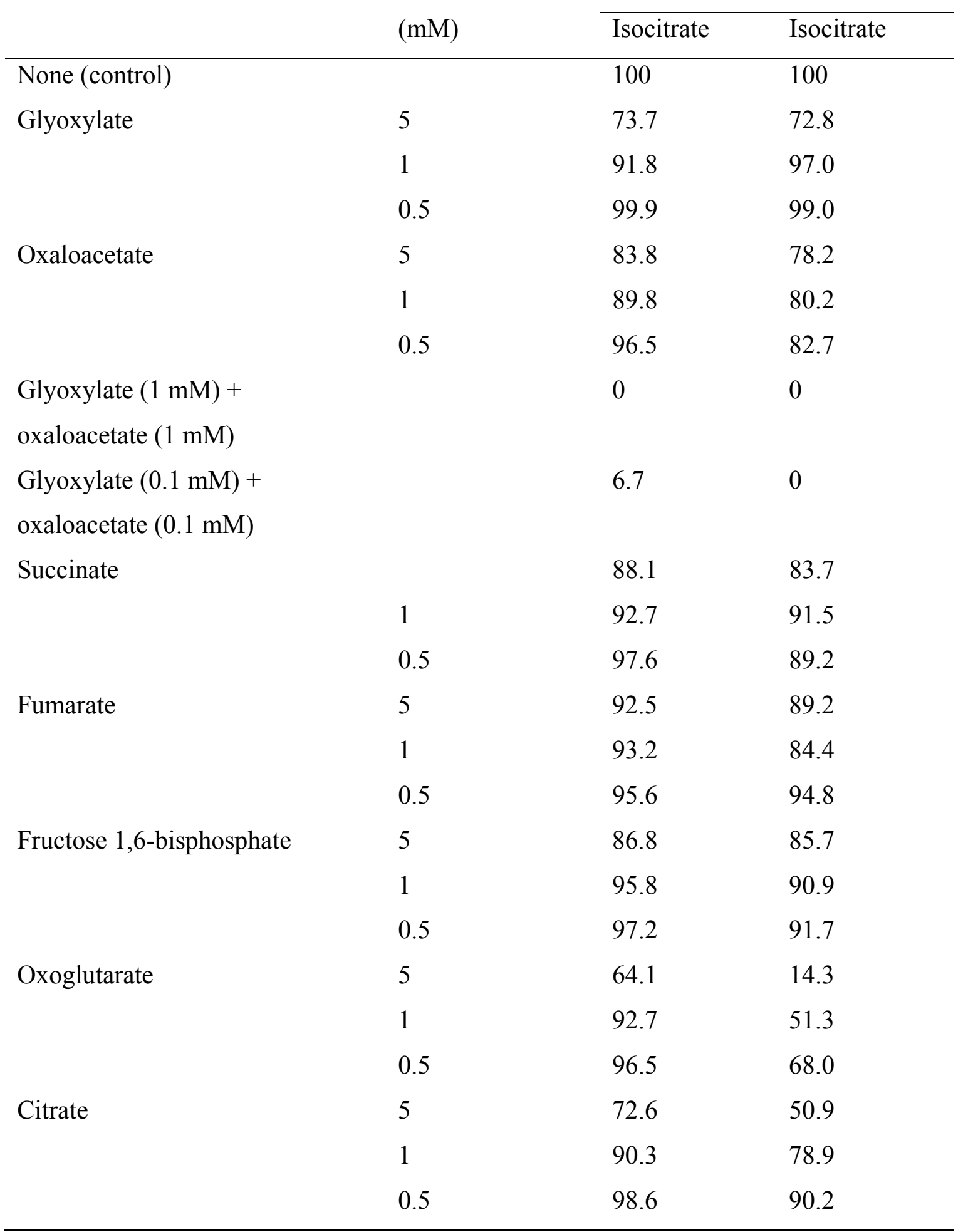

Table 4. Effect of nucleotides on ICDH activity from turbot larvae (*)

\begin{tabular}{llll}
\hline $\begin{array}{l}\text { Nucleotide } \\
\text { concentration }(\mathrm{mM})\end{array}$ & \multicolumn{2}{l}{ Specific activity (mUnits/mg protein) } \\
\cline { 2 - 4 } & AMP & ADP & ATP \\
\hline 5.0 & 29.4 & 22.0 & 0.0 \\
\hline
\end{tabular}




\begin{tabular}{llll}
\hline 1.0 & 33.0 & 29.2 & 4.7 \\
0.5 & 35.1 & 35.6 & 17.3 \\
\hline
\end{tabular}

The activity was measured at $\mathrm{pH} 7.5$ with $\mathrm{MgCI}_{2}(1 \mathrm{mM})$ and isocitrate $(0.1 \mathrm{mM})$ in the assay.

(*) Control activity $=38.4 \mathrm{mU} / \mathrm{mg}$ soluble protein.

Fig. 1. (A) The effect of $\mathrm{pH}$ on isocitrate dehydrogenase activity was measured as described in Materials and Methods but using 0.1M imidazole- $\mathrm{HCl}(\mathrm{O}), 0.1 \mathrm{M}$ Tris- $\mathrm{HCl}$ $(\bullet)$ and $0.1 \mathrm{M}$ glycine-NaOH ( $\square$ ) as buffers for the appropriate $\mathrm{pH}$ values. (B) Effect of $\mathrm{pH}$ on isocitrate dehydrogenase stability. The same buffers were used in this study. See text for further explanations.

Fig. 2. The effect of temperature on ICDH activity. (A) Temperature dependence, (B) Arrhenius plot.

Fig. 3. The effect of salt concentration on $\mathrm{ICDH}$ activity. $\mathrm{NaCl}(\mathrm{O}), \mathrm{KCI}(\bullet), \mathrm{CaCl}_{2}(\square)$ and $\mathrm{CuSO}_{4}(\mathbf{\square})$.

Fig. 4. The effect of isocitrate concentration on ICDH activity, in presence $(\bullet)$ and absence $(\mathrm{O})$ of $2 \mathrm{mM} \mathrm{MgCl} 2$

Fig. 5. The effect of $\mathrm{NADP}^{+}$concentration on ICDH activity, in presence $(\bullet)$ and absence $(\mathrm{O})$ of $2 \mathrm{mM} \mathrm{MgCl}$.

Fig. 6. The effect of $\mathrm{Mg}^{2+}$ concentration on ICDH activity.

Fig. 7. The effect of iodoacetate on ICDH stability at different $\mathrm{pH}$ values. The incubation mixtures were made of larval extract and buffer $(\mathrm{O})$, buffer $+30 \mathrm{mM}$ iodoacetate (匹), and buffer $+30 \mathrm{mM}$ iodoacetate $+30 \mathrm{mM}$ isocitrate $(\bullet)$. See text for further explanations. 